\title{
Adolescent Pregnancy: Epidemiological Survey in Schools and Obstetrical Outcomes in Douala (Cameroon)
}

\author{
Essome Henri ${ }^{1,2 *}$, Eposse Ekoube Charlotte ${ }^{1,2}$, Egbe Obinchemti Thomas ${ }^{3,4}$, D. C. Kedy Koum², \\ Halle Ekane Gregory ${ }^{3,4}$, Nana Njamen Théophile ${ }^{3,4}$, Penda Ida Calixte ${ }^{1,2}$, Boten Merlin1, \\ Tocki Toutou Grâce' ${ }^{1}$, Foumane Pascal ${ }^{5}$
}

\author{
${ }^{1}$ Laquintinie Hospital in Douala, Douala, Cameroon \\ ${ }^{2}$ Faculty of Medicine and Pharmaceutical Sciences of Douala, University of Douala, Douala, Cameroon \\ ${ }^{3}$ Douala General Hospital, Douala, Cameroon \\ ${ }^{4}$ Faculty of Health Sciences of Buea, University of Buea, Buea, Cameroon \\ ${ }^{5}$ Faculty of Medicine and Biomedical Sciences of Yaoundé, University of Yaounde 1, Yaounde, Cameroon \\ Email: ^essometocky@yahoo.com
}

How to cite this paper: Henri, E., Charlotte, E.E., Thomas, E.O., Kedy Koum, D.C., Gregory, H.E., Théophile, N.N., Calixte, P.I.., Merlin, B., Grâce, T.T. and Pascal, F. (2020) Adolescent Pregnancy: Epidemiological Survey in Schools and Obstetrical Outcomes in Douala (Cameroon). Open Journal of Obstetrics and Gynecology, 10, 1163-1175.

https://doi.org/10.4236/ojog.2020.1090110

Received: July 17, 2020

Accepted: September 4, 2020

Published: September 7, 2020

Copyright ( 2020 by author(s) and Scientific Research Publishing Inc. This work is licensed under the Creative Commons Attribution International License (CC BY 4.0).

http://creativecommons.org/licenses/by/4.0/ (c) (i) Open Access

\begin{abstract}
Introduction: According to the World Health Organization (WHO), adolescence is the period of growth between 10 and 19 years of age. Complications from pregnancy are the second leading cause of death for adolescent girls aged 15 to 19 worldwide. Objective: In order to reduce the phenomenon of early pregnancy, we set out to determine its prevalence as well as its outcome among adolescent girls in secondary schools in the Douala $3^{\text {rd }}$ district in Cameroon. Methodology: To achieve our objective, we conducted an analytical case-control study from November 08, 2018 to June 26, 2019, in ten secondary establishments in the Douala $3^{\text {rd }}$ district. Included in the study were all adolescent girls, students in one of the secondary schools in the said district who agreed to participate in the study. Data analysis was done using SPSS 20.0 software. The significance threshold was set at $p<0.05$. Results: A total of 445 adolescent girls were selected, including 89 cases and 356 controls. In $87.6 \%$ of the cases, the pregnancy was accidental and $58.4 \%$ used voluntary abortion. The univariate analysis of the results showed that the factor associated with the occurrence of teenage pregnancies was the age above 17 years $(\mathrm{OR}=1.44 ; \mathrm{CI}=1.31-1.59)(\mathrm{p}=0.001)$. Conclusion: At the end of our study, it appeared that early pregnancies exist in Cameroonian schools with a high rate of $6.57 \%$ and an appeal to illegal abortion (62.9\%).
\end{abstract}

\section{Keywords}

Pregnancy, Adolescence, Clandestine Abortion 


\section{Introduction}

Adolescence is the period of growth and development which takes place between childhood and adulthood, that is to say 10 and 19 years. It is a period of critical transition in life and is characterized by a significant rate of growth and transformation. It is a phase of preparation for adulthood during which key stages of development take place [1].

Worldwide, around 16 million adolescent girls aged 15 to 19 and one million adolescent girls under the age of 15 give birth each year; which represents nearly $11 \%$ of global births. $95 \%$ of these births take place in developing countries [2]. Almost half of the countries in sub-Saharan Africa for which information is available are classified as "red", meaning that they have adolescent fertility rates above 100 births per 1000 adolescent girls. These countries are those of West Africa, Central Africa, East Africa and Southern Africa. The proportions recorded by Niger, the Democratic Republic of Congo and Mali are among others high, with 192,168 and 167 births per 1000 adolescent girls, respectively [3]. Teenage pregnancies have been the subject of numerous studies around the world. According to a study conducted by Dryfoos in 1996 in the United States, early pregnancies are frequent in societies characterized by poverty, low education level and families headed by a mother who gave birth to their first child at adolescence [4]. Teenage pregnancy is also associated with other problem behaviors, such as alcohol and drug use and early initiation of sexual activity, which have been identified as predictors of pregnancy [5]. A study done in various European countries by Imamura et al. made it possible to group these factors into 5 groups: socio-demographic factors, family structure and stability, data related to education, behaviors at risk for health, knowledge, accessibility and acceptability of family planning [6]. According to the United Nations Population Fund (UNPF), in Cameroon, fertility remains early. The adolescent fertility rate represented $12 \%$ of general fertility in 2015 , while in 2018 ; this rate was $16.31 \%$ [7] [8].

Early pregnancies can have consequences on the health of adolescent girls (toxemia, anemia, nephropathy, cephalo-pelvic disproportion, hemorrhage, tears, obstetric fistulas, depressive disorders and maternal mortality) as well as that of the fetus they carry (low birth weight, fetal distress, and neonatal asphyxia, prematurity and fetal mortality) [9]. It is noted that the younger the mother, the greater the health risk for the child. This can be explained by the fact that these girls are more vulnerable than adult women to the risks of complications linked to pregnancy and birth, because not only their gynecological state is not ready and also their pelvic growth is not finished either [10]. These pregnancy-related complications are the second leading cause of death for girls aged 15 to 19 worldwide. It is also noted that three million unsafe abortions take place among girls aged 15 to 19 each year, which increases maternal mortality and leads to lasting health problems. In Africa and Asia, around 13\% of maternal deaths are linked to unsafe abortions [9] [11]. In adolescent girls, pregnancy can 
also have economic and social consequences. Many young girls have to drop out of school when they become pregnant. However, a young girl with little or no education will have fewer skills and fewer chances of finding a job [2].

Given the high prevalence of teenage pregnancies, the seriousness of complications and the maternal and fetal life threat at stake worldwide, in Africa, particularly in Cameroon; given the scarcity of studies on this subject in the city of Douala, we wondered about the existence of teenage pregnancies in secondary establishments in the Douala $3^{\text {rd }}$ district as well as their outcomes in order to better combat this phenomenon of early pregnancy.

\section{Methodology}

\subsection{Type of Study}

It was a case-control analytical study.

\subsection{Study Location}

We carried out our study in the city of Douala, specifically in secondary schools of Douala $3^{\text {rd }}$ district. Ten schools were chosen randomly including 4 private secondary schools and 6 public secondary schools:

Oyack High School;

Bobongo Petit-Paris Bilingual High School;

Ngodi-Bakoko Bilingual High School;

Nylon Brazzaville Bilingual Secondary school;

Nylon Technical School Douala;

Ndogpassi High School;

Perfection Bilingual College;

Perle Bilingual College;

Piedjou Multilingual Multipurpose Institute;

Pozam College.

\subsection{Period and Duration of the Study}

We conducted our study from November 08, 2018 to June 26, 2019, duration of seven months.

\subsection{Target Population}

Our target population consisted of school adolescents from Douala $3^{\text {rd }}$ district.

\subsection{Source Population}

Our source population consisted of all the pupils of the secondary schools of Douala $3^{\text {rd }}$ selected in our study.

\subsection{Inclusion Criteria}

Was included any pupil from one of the secondary schools of Douala $3^{\text {rd }}$ having an age between 10 and 19 years old and agreeing to participate in the study with 
the informed consent of a parent.

Cases and controls: was considered as a case that declared having conceived at least once while the control was exempt.

\subsection{Exclusion Criteria}

Excluded from the study were those whose survey sheets were incomplete or poorly completed.

\subsection{Sample Size}

The sampling method was continuous and exhaustive. The minimum sample size was calculated according to the Schlesselman formula below [12]:

$$
n=\left(\frac{r+1}{r}\right) \frac{\bar{p}(1-\bar{p})\left(z \beta+\frac{z \alpha}{2}\right)^{2}}{\left(p_{1}-p_{2}\right)^{2}}
$$

$n$ : Minimum size per group.

$r$. Case-control ratio $(\mathrm{r}=1 / 4) 22$.

$p$ : Variability measurement (similar to standard deviation).

$Z \frac{\alpha}{2}:$ standardized level of significance $=1.96$.

$Z=$ Standardized power $=0.84$.

$p_{1}$ : prevalence of adolescent girls having started their reproductive life, i.e. $25 \%$ according to the 2011 EDS-MICS report in Cameroon [13].

$p_{2}$ : prevalence of adolescent girls who have already had sexual intercourse, i.e. $81 \%$ according to the 2011 EDS-MICS report in Cameroon [13].

After numerical application of this formula, the case group was made up of at least 83 cases for 332 controls with a total number of 415 participants.

The data were collected using a pre-tested questionnaire explained and distributed to female students in their respective classes during recess in the absence of male students.

The variables of interest for this study were

- Age at onset of pregnancy (ies);

- Number of pregnancies already had;

- Desire or not of pregnancy;

- Author of pregnancy;

- Becoming pregnant;

- If abortion, reason for the abortions.

\subsection{Data Analysis}

Data was entered using the CSPro 7.0 software and analyzed using SPSS version 20.0 software. The data comparison was carried out using the Chi-Square test, odds ratio and the $95 \%$ confidence interval estimate to see if there are any associations. A p-value less than 0.05 was considered to be statistically significant. 


\section{Results}

At the end of our study, 2448 girls were interviewed. In total, we had 161 cases of pregnancies declared and 2287 girls who had never conceived a frequency of $6.57 \%$. In the end, 445 adolescent girls met the inclusion criteria, including 89 cases and 356 controls (Figure 1).

Among adolescents who had already conceived, 62.9\% were 17 years of age or less at the time of their first pregnancy and $37.1 \%$ were over 17 years of age at the time of their first pregnancy (Table 1).

Among the 89 adolescent girls who had already conceived, 78 (87.7\%) had already been pregnant once while $10.1 \%, 1.1 \%$ and $1.1 \%$ had already been pregnant two, three and five times respectively (Table 2).

Among those who had ever conceived, only 9.0\% of girls wanted it. For 78 girls $(87.6 \%)$, the pregnancy was accidental. Three girls conceived after being raped (Table 3 ).

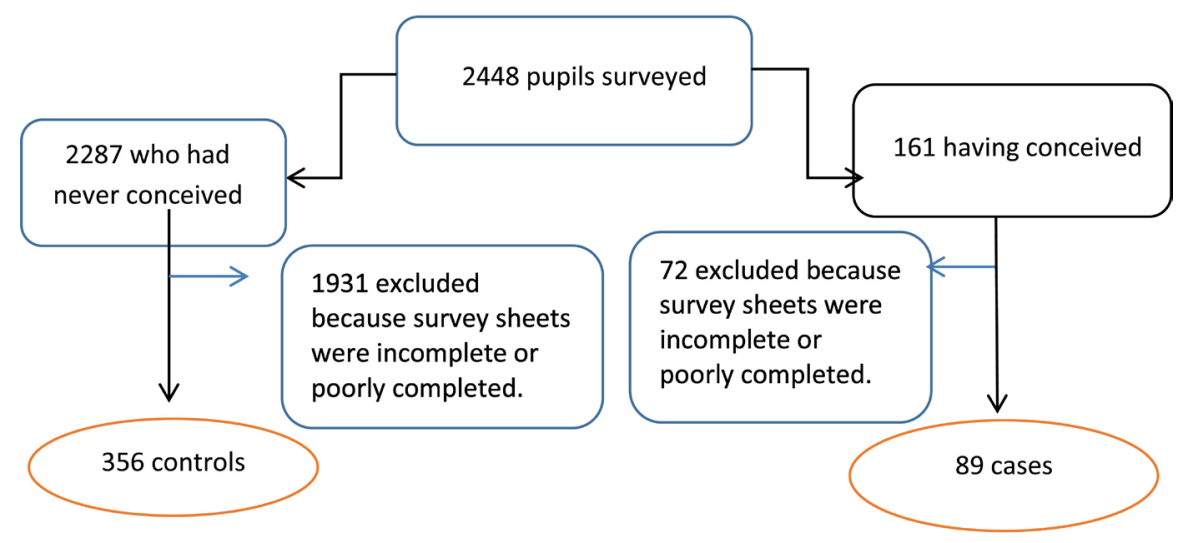

Figure 1. Distribution of the study population.

Table 1. Distribution of cases according to their age at the onset of the first pregnancy.

\begin{tabular}{ccc}
\hline Age & Frequency $(\mathbf{N}=\mathbf{8 9})$ & (\%) \\
\hline 17 years & 56 & 62.9 \\
$>17$ years & 33 & 37.1 \\
Total & 89 & 100 \\
\hline
\end{tabular}

Table 2. Distribution of cases according to the number of pregnancies.

\begin{tabular}{ccc}
\hline Number of pregnancies & Frequency $(\mathbf{N}=\mathbf{8 9})$ & $(\%)$ \\
\hline 1 & 78 & 87.7 \\
2 & 9 & 10.1 \\
3 & 1 & 1.1 \\
4 & 0 & 0.0 \\
5 & 1 & 1.1 \\
Total & 89 & 100.0 \\
\hline
\end{tabular}


Among the 89 adolescent girls who had already conceived, $58.4 \%$ had a clandestine abortion, $36 \%$ gave birth and $5.6 \%$ had a spontaneous abortion (Table 4 ).

The main reasons cited by the girls who had an abortion were:

1) Fear of parents' reaction $(36.5 \%)$;

2) Fear of dropping out of school (26.9\%);

3 ) Fear of the reaction and the judgment of others (15.4\%);

4) The fear of the burden that the child will pose in the future (13.5\%);

5) The fear of being expelled from school (5.8\%) (Table 5).

The main authors of pregnancies were students with a percentage of $40.4 \%$ followed by salaried employees and pupils with a percentage of $24.7 \%$ and $24.7 \%$. Two authors were unknown; (these are two of the three pregnancies following rape) (Table 6).

However, we note that 08 students (2.2\%) among those who had not yet been pregnant, wanted to have children before 19 years, and 17 students $(4.8 \%)$ were indecisive (Table 7).

In our study we found an association between the age of the adolescent girl and the occurrence of early pregnancies. Indeed, having an age higher than 17 years was a predictive factor $(\mathrm{OR}=1.44 ; \mathrm{CI}=1.31-1.59)$ of early pregnancy and this significantly $(\mathrm{p}=0.001)$ (Table 8$)$.

Table 3. Distribution of cases according to the planning or not of the pregnancy.

\begin{tabular}{ccc}
\hline & Frequency $(\mathbf{N}=\mathbf{8 9})$ & $(\%)$ \\
\hline Accidental & 78 & 87.6 \\
Desired & 8 & 9.0 \\
Rape & 3 & 34 \\
Total & 89 & 100 \\
\hline
\end{tabular}

Table 4. Distribution of cases according to the outcome of pregnancies.

\begin{tabular}{ccc}
\hline Outcome of pregnancies & Frequency $(\mathbf{N}=\mathbf{8 9})$ & $(\%)$ \\
\hline Voluntary abortion & 52 & 58.4 \\
Delivery & 32 & 36.0 \\
Spontaneous abortion & 5 & 5.6 \\
Total & 89 & 100 \\
\hline
\end{tabular}

Table 5. Distribution of cases according to the different reasons for voluntary abortion.

\begin{tabular}{ccc}
\hline Reason for abortion & Frequency $(\mathbf{N}=\mathbf{5 2 )}$ & (\%) \\
\hline Fear of parents' reaction & 19 & 36.5 \\
Fear of dropping out of school & 14 & 26.9 \\
Fear of the reaction and the judgment of others & 8 & 15.4 \\
The fear of the burden that the child will pose in the future & 7 & 5.8 \\
The fear of being expelled from school & 3 & 1.9
\end{tabular}


Table 6. Distribution according to the authors of pregnancies.

\begin{tabular}{ccc}
\hline Author of pregnancy & Frequency $(\mathbf{N}=\mathbf{8 9})$ & $\%$ \\
\hline Pupil & 22 & 24.7 \\
Student & 36 & 40.4 \\
Salaried employee & 22 & 24.7 \\
Unknown & 2 & 2.2 \\
Trader & 7 & 7.9 \\
\hline
\end{tabular}

Table 7. Distribution of controls according to the desire or not to conceive before 19 years.

\begin{tabular}{ccc}
\hline Desire of controls to conceive & Frequency $(\mathbf{N}=\mathbf{3 5 6})$ & (\%) \\
\hline Yes & 8 & 2.2 \\
Indecisive & 17 & 4.8 \\
No & 331 & 93.0 \\
Total & 356 & 100 \\
\hline
\end{tabular}

Table 8. Distribution of the study population according to age.

\begin{tabular}{ccccc}
\hline Age & $\begin{array}{c}\text { Cases } \mathbf{N}=\mathbf{8 9} \\
\mathbf{n}(\%)\end{array}$ & $\begin{array}{c}\text { Controls } \mathbf{N}=356 \\
\mathbf{n}(\%)\end{array}$ & OR (CI 95\%) & P \\
\hline$>17$ years & $73(82.0)$ & $153(43.0)$ & $1.44(1.31-1.59)$ & 0.001 \\
$\leq 17$ years & $16(18.0)$ & $203(57.0)$ & $0.32(0.20-0.50)$ & \\
\hline
\end{tabular}

\section{Discussion}

The aim of our study was to determine the frequency of teenage pregnancies in secondary schools in the Douala $3^{\text {rd }}$ district and to assess the outcome. It was carried out on a sample of 445 adolescent girls including 89 cases and 356 controls. It was an analytical case-control study.

The Douala $3^{\text {rd }}$ district is as cosmopolitan as the whole city and shines through a lack of urbanization. The commercial activity is the majority there and it is usual to find businesses of all kinds surrounding the periphery of a school.

This is why we find near certain educational establishments in this administrative sub-division selling of alcoholic beverages, games rooms, hostels all reported in the literature as predictive factors for sexual depravity and early pregnancies [5].

Early pregnancy is a stolen adolescence and a compromised future. Beyond the usual thesis and anti-thesis approach in research work, it seems to us appealing to stop on certain clichés appeared in our results in order to draw useful lessons from them after a cold analysis taking into account the sacred character of facts.

The analysis of our data attests to the fact that early pregnancy is a fact in school in a percentage of $6.57 \%$ in the Douala $3^{\text {rd }}$ district and $32.58 \%$ of these pregnancies were the work of salaried employees $(22$ cas) and traders (07 cas), 
there are two unspecified cases following rape.

Starting from an empirical observation of the environment of Douala $3^{\text {rd }}$, it appears that the adolescent's journey, from the family home to her school is strewn with sexual predators and activities incompatible with the harmonious development of a growing being.

Among the 89 adolescent girls who had already conceived, 78 (87.7\%) had already been pregnant once while $10.1 \%, 1.1 \%$ and $1.1 \%$ had already been pregnant two, three and five times respectively and $62.9 \%$ were before the physiological maturity of 18 years (Table 1, Table 2, Table 3, Table 6). Our findings join those of literature [14].

Among those who had ever conceived, only $9.0 \%$ of girls wanted it. For 78 girls (87.6\%), the pregnancy was accidental, implying unwanted implication. This mask reflects the failure or absence of an urbanization policy and access to basic care such as family planning services or a deficit in educational programs both in our geographic or national area but also beyond because Ayele et al. in Ethiopia report the same findings and therefore the same concerns [15].

The weight of the look others, of stigmatization, the fear of dropping out of studies and especially the fear of the very dreaded parental reaction pushes these fragile beings to unsafe abortions [9] [11] in a proportion of 58.4\% in our sample not superimposable on the $4.52 \%$ of Gbaguidi et al. in Benin [14]. The Beninese tradition is clearly present in households and therefore not permissive to certain practices such as taking life.

Since voluntary termination of pregnancy is illegal in Cameroon, it is feared that many of these adolescent girls will have a dark obstetrical future due to the known complications of these clandestine abortions [9].

The age above 17 years exposed significantly more than once to the occurrence of an early pregnancy in our study $(\mathrm{OR}=1.44 ; \mathrm{CI}=1.31-1.59)(\mathrm{p}=0.000)$ confirming this does the work of other authors such as Ayele et al. in northern Ethiopia where being 18 - 19 years old was a risk factor for pregnancy [15].

As our system for collecting maternal deaths in the community is not efficient enough, there is also a strong fear that some of these clandestine abortions may have resulted in deaths from either hemorrhagic or infectious causes or have remained in statistical silence.

\section{Limitations of the Study}

The declarative nature of the responses associated with the age of our respondents was a handicap given the strong subjectivity that often surrounds this type of study; it also contributed to the "sensitive and delicate" nature of the theme addressed here, despite the confidentiality provided by the anonymity of the survey.

\section{Conclusions}

At the end of our study it appeared that the Douala $3^{\text {rd }}$ district is a lodging fa- 
vorable to early pregnancies by default of urban demarcation between the activities of enjoyments and the school framework; $6.57 \%$ of early pregnancies were declared there with a strong resort to clandestine abortion (62.9\%) and some of these pregnancies were the work of salaried employees (22 cases), traders (07 cases) and rape (03 cases).

These findings raise the problem of the normative urbanization of our cities, as well as motivate other subsequent studies focusing on family factors predicting early pregnancies because 08 students $(2.2 \%)$ in the control group declared that they wished to be pregnant before 19 years old and 8 students (9\%) of the case group wanted it.

\section{Acknowledgements}

The authors thank the managers of the various establishments as well as their teachers for the various facilities granted to them in carrying out this study.

\section{Contribution of Authors}

Essome designed the study, collected the data and wrote the manuscript. Tocki carried out the literature review as well as the formatting of the manuscript. Eposse, Egbe, Kedy Koum, Halle, Nana, Penda and Boten have read and corrected the manuscript. Foumane directed the study and supervised the writing of the manuscript. All authors have read and validated the final version of the manuscript.

\section{Conflicts of Interest}

The authors declare no conflicts of interest regarding the publication of this paper.

\section{References}

[1] OMS (2018) Développement des adolescents [Internet]. Organisation Mondiale de la santé, Genève. https://www.who.int/maternal_child_adolescent/topics/adolescence/dev/fr

[2] OMS (2018) Grossesse chez les adolescentes [Internet]. Organisation Mondiale de la Santé, Genève. http://www.who.int/fr/news-room/fact-sheets/detail/adolescent-pregnancy

[3] Hervish, A. and Clifton, D. (2012) Le Rapport sur le statut des adolescents et des jeunes en Afrique subsaharienne: Possibilités et enjeux. UNFPA, Johannesburg.

[4] Dryfoos, J.G. (1991) Adolescents at Risk: Prevalence and Prevention. Oxford University Press, New York.

[5] Coley, R.L. and Chase-Lansdale, P.L. (1998) Adolescent Pregnancy and Parenthood. Recent Evidence and Future Directions. American Psychologist, 53, 152-166. https://doi.org/10.1037/0003-066X.53.2.152

[6] Imamura, M., Tucker, J., Hannaford, P., Silva, M.O., Astin, M., Wyness, L., et al. (2007) Factors Associated with Teenage Pregnancy in the European Union Countries: A Systematic Review. European Journal of Public Health, 17, 630-636. https://doi.org/10.1093/eurpub/ckm014 
[7] Cameroun (2015) Fonds des Nations Unies pour la Population. Repositionnement de la planification familiale comme stratégie de développement. UNFPA, Yaoundé.

[8] Kassa, G.M., Arowojolu, A.O., Odukogbe, A.A. and Yalew, A.W. (2018) Prevalence and Determinants of Adolescent Pregnancy in Africa: A Systematic Review and Meta-Analysis. Reproductive Health, 15, 195. https://doi.org/10.1186/s12978-018-0640-2

[9] OMS (2007) Adolescentes enceintes: Apporter une promesse d'espoir dans le monde entier. Organisation Mondiale de la Santé, Genève.

[10] Chung, H.W., Kim, E.M. and Lee, J.-E. (2018) Comprehensive Understanding of Risk and Protective Factors Related to Adolescent Pregnancy in Low- and Middle-Income Countries: A Systematic Review. Journal of Adolescence, 69, 180-188. https://doi.org/10.1016/j.adolescence.2018.10.007

[11] OMS (2012) Mariages précoces, grossesses chez les adolescentes et les jeunes femmes. Organisation Mondiale Santé, Genève.

[12] Vallin, J., D’Souza, S. and Palloni, A. (1988) Mesure et analyse de la mortalité: Nouvelles approches. INED, $486 \mathrm{p}$.

[13] Institut National de la Statistique, Fédération International de Coaching (2012) Enquête démographique et de santé et à indicateurs multiples du Cameroun 2011. Calverton, 120-222.

[14] Gbaguidi, T. (2017) Grossesses en milieu scolaire dans l'arrondissement de Tchaourou (Bénin): Niveau, profil des femmes concernées et conséquences en matière de scolarisation. Tchaourou, une commune béninoise. Éditions science et bien commun [Internet].

https://scienceetbiencommun.pressbooks.pub/tchaourou/chapter/grossesses-en-mil ieu-scolaire-dans-larrondissement-de-tchaourou-benin-niveau-profil-des-femmes-c oncernees-et-consequences-en-matiere-de-scolarisation

[15] Ayele, B.G., Gebregzabher, T.G., Hailu, T.T. and Assefa, B.A. (2018) Determinants of Teenage Pregnancy in Degua Tembien District, Tigray, Northern Ethiopia: A Community-Based Case-Control Study. PLoS ONE, 13, e0200898.

https://doi.org/10.1371/journal.pone.0200898 


\section{Appendix: Data Collection Form}

Form $\mathrm{N}^{\circ} \ldots \mid$

Date: |____l____l___

\section{Sociodemographic Data}

\begin{tabular}{|c|c|c|c|c|c|c|c|}
\hline $\mathrm{N}^{\circ}$ & \multicolumn{6}{|l|}{ QUESTIONS } & CODE \\
\hline 01 & \multicolumn{6}{|c|}{ Name of establishment............................ } & |_|l_|_|_| \\
\hline 02 & $\begin{array}{l}\text { Type of establishment: } \\
\text { (precise catholic /_/; pre }\end{array}$ & $\begin{array}{l}\text { 1. General public } \\
\text { esbyterian /__/; isli }\end{array}$ & $\begin{array}{l}\text { 2. Technical pul } \\
\text { mic/_/) }\end{array}$ & \multicolumn{3}{|c|}{ 3. Private secular; 4. Denominational private } & L_ \\
\hline 03 & \multicolumn{6}{|l|}{ Age ............. } & |_- | \\
\hline 04 & $\begin{array}{l}\text { Religion: } 1 . \text { catholic; } \\
\text { Other (precise) ............. }\end{array}$ & $\begin{array}{l}\text { 2. Presbyterian; } \\
\ldots \ldots \ldots \ldots \ldots \ldots \ldots\end{array}$ & 3. Muslim; & \multicolumn{3}{|l|}{ 4. Animist; } & |_l \\
\hline 05 & $\begin{array}{l}\text { Marital status: } \\
5 \text {. Free union }\end{array}$ & 1. Married; & 2. Single; & \multicolumn{3}{|l|}{ 3. Divorced; } & L_ \\
\hline $05 a$ & If married, regime: & 1. Monogamy; & 2. Polygamy & & & & |_l \\
\hline 05b & \multicolumn{6}{|c|}{ If married, how old were you when you got married for the first time? ..................... } & |_l \\
\hline 06 & Region of origin: & $\begin{array}{l}1=\text { West } \\
6=\text { Littoral; }\end{array}$ & $\begin{array}{l}2=\text { Centre } \\
7 \text { = Adamawa; }\end{array}$ & $\begin{array}{l}3=\text { Nord } \\
8=\text { South-west }\end{array}$ & $\begin{array}{l}4=\text { South } \\
9=\text { Nord-west }\end{array}$ & $\begin{array}{l}5=\text { East; } \\
10=\text { Far nord }\end{array}$ & I \\
\hline 07 & Place of residence: ........ & . & $\ldots \ldots$ & & & & |_L \\
\hline
\end{tabular}

\section{Data Related to Pregnancy}

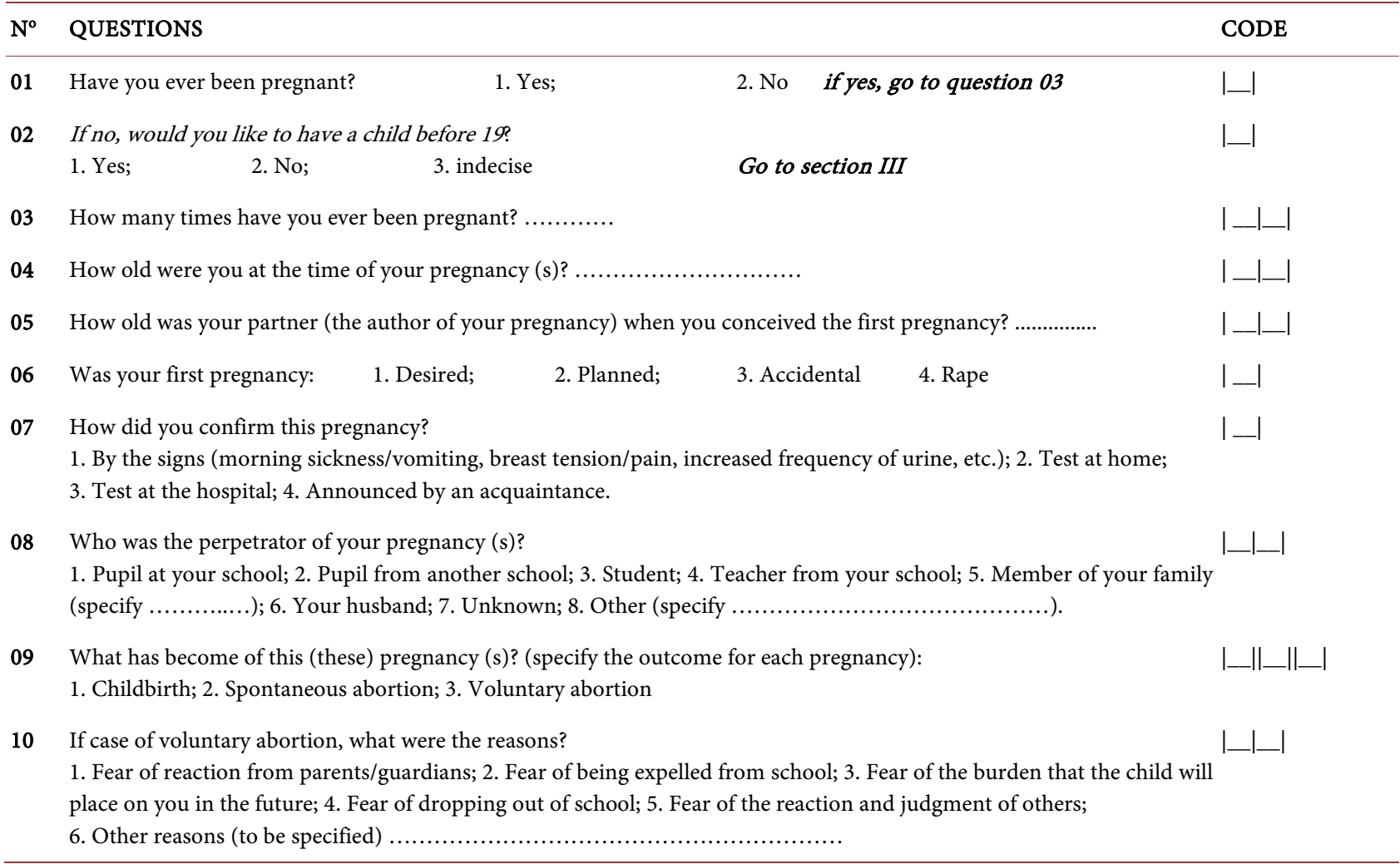




\section{Family Data}

$\mathbf{N}^{\circ}$ QUESTIONS

01 Who do you live with?

1. Father and mother; 2. Mother; 3. Father; 4. Grandparents; 5. Brother/sister

6. Husband; 7. Alone; 8 . Others (to be specified)

02 What is the marital status of the responsible person(s) with whom you live?

1. Single; 2. Cohabitation; 3. Married; 4. Divorced; 5. Widower

03 Profession of this person: 1. Trader; 2. Cultivator;

3. Domestic worker; 4. Housewife; 5. Employee;

6. Moto-taxi driver; 7. Others (to be specified)

04 Who takes care of your education (registration fees, school supplies, application fees, etc.)? 1. Parents; 2. Brother/sister; |_|

3. Tutor;

4. Yourself totally; 5 . You yourself in part;

6. Other person (to be specified)

05 What means do you use to get to school? 1. Walking;

2. School bus; 3 . Motorcycle; 4 . Vehicle of the house; 5 . Your own vehicle;

6. Others (to be specified)

06 Do you get what to eat at school (pocket allowance)? 1. Yes; 2. No

07 What type of family are you from? 1. Nuclear; 2. Single parent; 3. Polygamy; 4. Recomposed; 5. Separated.

08 Position in the siblings: 1. Elder; 2. Benjamine; 3. Only girl;

4. Only daughter; 5 . Any position.

09 At what age did your mother first conceive?

10 Do you have sisters who conceived between the ages of 10 and 19? 1. Yes; 2. No

\section{Data Related to Education}

\begin{tabular}{|c|c|c|}
\hline $\mathbf{N}^{\circ}$ & QUESTIONS & CODE \\
\hline 01 & Class attended: ..................... & |_l_l | \\
\hline 02 & Do you want to reach the top? 1 . Yes; 2 . No & l一 \\
\hline 03 & 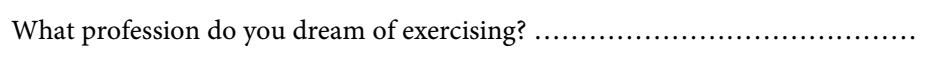 & I \\
\hline 04 & Do you have any hope of getting there? 1 . Yes; 2 . No & l \\
\hline 05 & 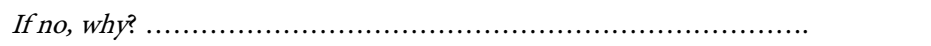 & L \\
\hline
\end{tabular}

\section{Data Related to Sexuality}

\begin{tabular}{|c|c|c|}
\hline $\mathrm{N}^{\circ}$ & QUESTIONS & CODE \\
\hline 01 & At what age did you have your first period (menarche)? ............. & 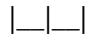 \\
\hline 02 & What do you think is the ideal age for a girl's first sexual intercourse? ..................... & |_l \\
\hline 03 & Have you ever had your first sexual encounter? 1 . Yes; 2 . No If no, go to 06 & \\
\hline 04 & If so, at what age? ...................... & |_l \\
\hline 05 & $\begin{array}{l}\text { What prompted your first sexual encounter? } 1 . \text { Curiosity; } 2 . \text { Envy; } 3 . \text { Influence of friends; } 4 . \text { Influence of family; } 5 . \\
\text { Partner influence; } 6 . \text { Rape; } 7 . \text { Others (to be specified) } \ldots \ldots \ldots \ldots \ldots \ldots \ldots \ldots \ldots \ldots\end{array}$ & 1 \\
\hline 06 & $\begin{array}{l}\text { Do you know about contraception? } \\
1 . \text { Yes; } 2 \text {. No If no, go to } 10\end{array}$ & I \\
\hline
\end{tabular}




\section{Continued}

$\mathbf{0 7}$ If yes, what methods of contraception do you know?

Natural methods

A. Abstinence [...]; B. Coitus interrupted [...]; C. Temperature method [...]

D. Knowledge of the menstrual cycle (Ogino-Knaus method) [...];

Barrier methods

E. Male condoms [...]; F. Female condoms [...]; G. Spermicide [...]

Hormonal contraception

H. Pill [...]; I. Injection [...]; J. Implant [...]

Intrauterine device

K. IUD [...]; L. Diaphragm [...]; M. Emergency contraception (morning after pill) [...]

08 Which one (s) do you use? 1. None 2. Corresponding letters

09 If none, why? 1. Personal desire; 2. Cost; 3. Refusal of the partner; 4. Ignorance; 5. Other (to be specified)

10 Where do you find information about sexuality? 1. Parents; 2. Brothers/sisters; 3. Friends/comrade; 4. Sexual partner; 5. Schools/courses; 6. Socio-educational clubs at school; 7. Television/radio; 8. Magazines/newspapers; 9.

Internet/social networks; 10 . None; 11 . Others

11 Do you discuss sexual and reproductive health with your parents/guardian? 1. Yes; 2. No

12 Do you think some of your classmates have undeserved grades because they are appreciated by teachers? 1 . Yes; 2 . No

\section{Risky Behaviors}

\begin{tabular}{|c|c|c|}
\hline $\mathbf{N}^{\circ}$ & QUESTIONS & CODE \\
\hline 01 & Do you consume the following products: A. Alcohol [...]; B. Cigarettes $[\ldots]$; C. Illicit substances $[\ldots] ;$ D. None $[\ldots]$ & |__ \\
\hline 02 & 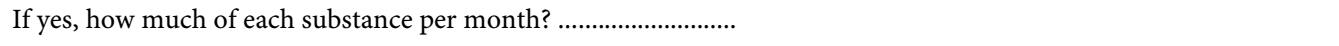 & |__ \\
\hline 03 & Do you have a boyfriend (s)? 1 . Yes; 2 . No If no, go to section VII & Ll \\
\hline 04 & If so, at what age did you have your first boyfriend? ............... & |___ \\
\hline 05 & How many sexual partners do you currently have? ............ & |__ \\
\hline 06 & How old are they? ................... & $\mid$ \\
\hline
\end{tabular}

\section{Knowledge, Acceptability and Accessibility to Family Planning Services}

\begin{tabular}{|c|c|c|}
\hline $\mathrm{N}^{\circ}$ & QUESTIONS & CODE \\
\hline 01 & Do you know about family planning services? 1. Yes; 2. No If no, go to S7Q04 & $1-1$ \\
\hline 03 & $\begin{array}{l}\text { If not why? } 1 . \text { Distance; } 2 . \text { Fear of cost; } 3 . \text { Useless; } \\
4 . \text { Others (to be specified) } \ldots \ldots \ldots \ldots \ldots \ldots \ldots \ldots \ldots \ldots \ldots \ldots \ldots \ldots \ldots \ldots \ldots \ldots \ldots\end{array}$ & I \\
\hline 04 & Do you have anything to add? & $\mid$ \\
\hline
\end{tabular}

Thank you!!!!! 